\title{
Comparison of the Morphology of Three Coronaviruses
}

\author{
By \\ Heather A. Davies and M. R. Maonadghton \\ Section of Electron Microscopy and Division of Communicable Diseases, \\ Clinical Research Centre, \\ Harrow, Middlesex, Fngland \\ With 3 Figures
}

Accepted August 22, 1978

\begin{abstract}
Summary
The morphology of three coronaviruses; avian infectious bronchitis virus strain Connecticut (IBV Conn), human coronavirus strain 229E (HCV 229 E) and mouse hepatitis virus strain 3 (MHV3), were examined by negative staining. Significant differences were found in the sizes of the three coronaviruses. Furthermore, three types of surface projection of the same lengths, but varying widths and morphology, were observed. Both IBV Conn and HCV $229 \mathrm{E}$ had bulbous projections characteristic of coronaviruses, although the projections of $\mathrm{HCV} 229 \mathrm{E}$ were somewhat thinner than those of IBV Conn. On the other hand, MHV3 particles had thin, cone-shaped surface projections, that were completely unlike typical coronavirus projections. The significance of these results is diseussed.
\end{abstract}

\section{Introduction}

Coronaviruses are a group of lipid-containing RNA viruses that have a unique morphology $(15,22)$. The virions are usually described as being large pleomorphic spherical particles with characteristic bulbous, widely-spaced surface projections that form a corona around the particles (15). The virus envelope contains lipid and appears to consist of a distinct pair of electron dense shells (15) and a singlestranded helical internal component that has been identified as ribonucleoprotein (10). At present, coronaviruses are classified almost entirely by means of their characteristic morphology, and although preliminary biochemical and serological criteria are now available for some coronaviruses (22), the relative difficulty in isolating and growing some of these viruses in cell culture for biochemical analysis means that for some time it will be necessary to classify many coronaviruses entirely by their morphological features.

Measurements of the sizes of various coronavirus species by different investigators using negative staining have revealed a large range in total diameters 
of between 50 and $220 \mathrm{~nm}$, with average total diameters ranging from 75 to $160 \mathrm{~nm}$ (15). Furthermore, the bulbous surface projections vary in shape and size, with lengths of between 12 and $24 \mathrm{~nm}$ (15). Few measurements of the width of these projections have been made. In some cases, long, thin, rod-like surface projections of length approximately $20 \mathrm{~nm}$ have been observed that bear little if any resemblance to 'typical' coronavirus projections $(1,3,4,16)$. Sometimes spherical dilations or $T$-shaped structures were observed at the distal end of these projections.

As no previous comparative studies have been made on the detailed structure of different coronaviruses, we have analysed the morphology by negative staining of three coronaviruses: avian infectious bronchitis virus strain Connecticut (IBV Conn), human coronavirus strain $229 \mathrm{E}$ (HCV 229 E) and mouse hepatitis virus strain 3 (MHV3). The results we have obtained are of importance in the morphological classification of coronaviruses.

\section{Materials and Methods}

\section{Virus Growth}

IBV strain Connecticut (IBV 46) was grown in 10-day old embryonated chicken eggs incubated at $37^{\circ} \mathrm{C}$ for 24 hours as previously described (11). HCV $229 \mathrm{E}$ was grown in monolayer cultures of embryo lung cells of the MRC continuous line at $33{ }^{\circ} \mathrm{C}$ for 32 hours in Eagles' BME with 2 per cent new born calf serum (13). MHV 3 was grown in confluent secondary mouse embryonic fibroblasts at $37^{\circ} \mathrm{C}$ for 72 hours in Eagles' MEM with 2 per cent foetal calf serum (10). Cell cultures containing HCV 229E and MHV 3 particles were frozen and thawed three times and then purified.

\section{Virus Purification}

All the purification steps were performed at $0^{\circ}$ to $4^{\circ} \mathrm{C}$. The virus suspension was clarified at $2000 \times g$ for 30 minutes, pelleted at $75,000 \times g$ for 1 hour and then resuspended in $1 \mathrm{ml}$ Dulbecco's phosphate buffered saline 'A' (PBSA). The resuspended virus was overlaid on to a linear 25 to 55 per cent $(w / w)$ sucrose gradient in PBSA and centrif. uged for 16 hours at $90,000 \times g$. The virus peak at $1.18 \mathrm{~g} / \mathrm{ml}$ was collected, diluted in PBSA and again layered onto a linear 25 to 55 per cent $(\mathrm{w} / \mathrm{w})$ sucrose gradient in PBSA and centrifuged for 16 hours at $90,000 \times \mathrm{g}$. Peak fractions at $1.18 \mathrm{~g} / \mathrm{ml}$ were examined by electron mieroscopy.

\section{Electron Microscopy}

One aliquot of each virus sample was negatively stained with 2 per cent $(w / v)$ potassium phosphotungstate $\mathrm{pH} 6.5$ and a second with 0.5 per cent $(\mathrm{w} / \mathrm{v})$ uranyl acetate, $\mathrm{pH} 4.4$, and examined in a Philips EM 300 electron microscope. Three features of coronavirus morphology were examined, namely, the envelope diameter (excluding. surface projections) and the length and width of the surface projections. Approximately 50 envelope diameters of each virus species were measured. In each case two measurements of diameter were taken and the average value was used in subsequent calculations. For elliptical shaped virus particles, one measurement was taken across the long axis and the other across the short axis (18). Between 50 and 100 measurements of surface projection lengths and widths were made for each virus species. Lengths were measured from the boundary of the virus envelopes to the distal end of the projections and widths were measured at the widest parts of the projections. An analysis of variance was performed on the measurements for each feature, using each staining method, to determine whether the means for the three viruses differed significantly. 

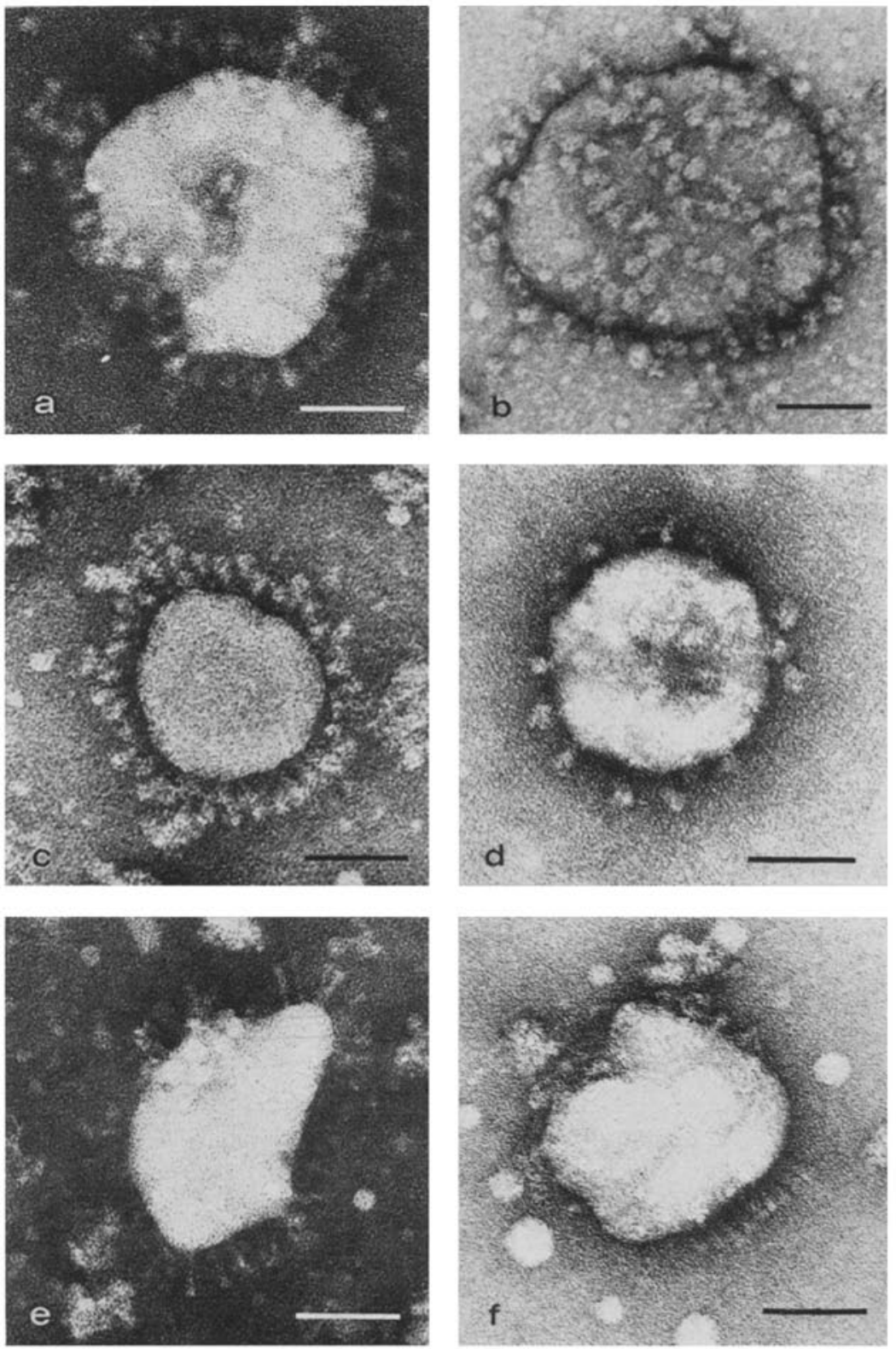

Fig. 1. Negatively stained preparations of purified coronavirus particles. $a$ IBV Conn stained with 2 per cent potassium phosphotungstate, pH $6.5 ; b$ IBV Conn stained with 0.5 per cent uranyl acetate, $\mathrm{pH} 4.4 ; c \mathrm{HCV} 229 \mathrm{E}$ stained with 2 per cent potassium phosphotungstate, pH $6.5 ; d \mathrm{HCV} 229 \mathrm{E}$ stained with 0.5 per cent uranyl acetate, $\mathrm{pH} 4.4 ; e \mathrm{MHV} 3$ stained with 2 per cent potassium phosphotungstate, $\mathrm{pH} 6.5 ; f \mathrm{MHV} 3$ stained with 0.5 per cent uranyl acetate, $p H 4.4$. The bar represents $50 \mathrm{~nm}$ 


\section{Results}

\section{Virus Purification and Morphology}

Purified coronavirus particles of density $1.18 \mathrm{~g} / \mathrm{ml}$ from sucrose gradients were examined in this study as only these particles comprised complete infectious particles (MaCNaUGHTon, manuscript in preparation). Nevertheless, the morphology of virus particles of other densities was similar to that of the complete partieles. Figure 1 shows electron micrographs of IBV Conn, HCV $229 \mathrm{E}$ and MHV 3 examined by negative staining with potassium phosphotungstate (KPT) and uranyl acetate (UA). Typical, more or less spherical coronavirus particles were observed with a]most complete coronas of surface projections. The particles remained intact with both negative stains as judged by the exclusion of stain from them.

\section{Variations in Size}

Table 1 summarises the results of measurements of envelope diameters of IBV Conn, HCV $229 \mathrm{E}$ and MHV 3 using purified virus preparations, negatively stained with KP' or UA. For each stain IBV Conn was highly significantly greater than the other two $(p<0.001)$, while the other two were less, but still significantly, different from each other. IBV Conn and MHV 3 showed no significant difference as between one stain and the other, but HCV $229 \mathrm{E}$ had a highly significantly greater diameter $(p<0.001)$ when stained with UA than when stained with KPT. With KPT staining MHV3 had a larger average diameter then HCV $229 \mathrm{E}$ $(p=0.001)$, while the reverse was true for UA staining $(0.005>p>0.001)$.

Table 1. Diameters of the envelopes of three coronaviruses determined using different negative stains

\begin{tabular}{|c|c|c|c|c|c|c|c|c|}
\hline \multirow[b]{2}{*}{$\begin{array}{l}\text { Corona- } \\
\text { virus } \\
\text { species }\end{array}$} & \multicolumn{4}{|c|}{$\begin{array}{l}\text { Potassium phosphotungstate } \\
\text { diameters }(\mathrm{nm})^{\mathrm{a}}\end{array}$} & \multicolumn{4}{|c|}{ Uranyl acetate diameters $(\mathrm{nm})^{b}$} \\
\hline & $\begin{array}{l}\text { Number } \\
\text { of } \\
\text { obser. } \\
\text { vations }\end{array}$ & Mean & $\begin{array}{l}\text { Stand- } \\
\text { ard } \\
\text { error }\end{array}$ & Range & $\begin{array}{l}\text { Number } \\
\text { of } \\
\text { obser- } \\
\text { vations }\end{array}$ & Mean & $\begin{array}{l}\text { Stand- } \\
\text { ard } \\
\text { error }\end{array}$ & Range \\
\hline IBV Conn & 41 & 129.5 & 3.8 & $90-197$ & 52 & 125.9 & 2.5 & $90-171$ \\
\hline $\mathrm{HCV} 229 \mathrm{E}$ & 49 & 89.6 & 1.5 & $67-123$ & 61 & 108.9 & 2.3 & $75-152$ \\
\hline MHV 3 & 41 & 96.5 & 1.3 & $78--116$ & 47 & 100.0 & 1.7 & $76-121$ \\
\hline
\end{tabular}

a. Negative staining with 2 per cent potassium phosphotungstate, $\mathrm{pH} 6.5$

- Negative staining with 0.5 per cent uranyl acetate, $\mathrm{pH} 4.4$

Figure 2 shows histograms of the envelope diameters of the three coronaviruses stained with KPT. Most HCV $229 \mathrm{E}$ and MHV 3 particles had envelope diameters showing little spread around the mean values. However, there was a wider spread in the diameters of IBV Conn envelopes. The diameters of UA stained virus envelopes were distributed as in Figure 2 (not shown), except for HCV $229 \mathrm{E}$ (Table 1).

\section{Morphology of the Surface Projections}

Three types of surface projections were found. Those of IBV Conn (Fig. 1a and b) and HCV $229 \mathrm{E}$ (Figs. 1c and d) were bulbous or 'tear-drop' shaped and 
were widely spaced on the virus envelope. However, those of MHV3 (Figs. 1e and f) were 'cone-shaped' with the thicker, flat part at the distal end. They were spaced closely together on the virus envelope though not as many particles exhibited complete coronas as IBV Conn and HCV $229 \mathrm{E}$.

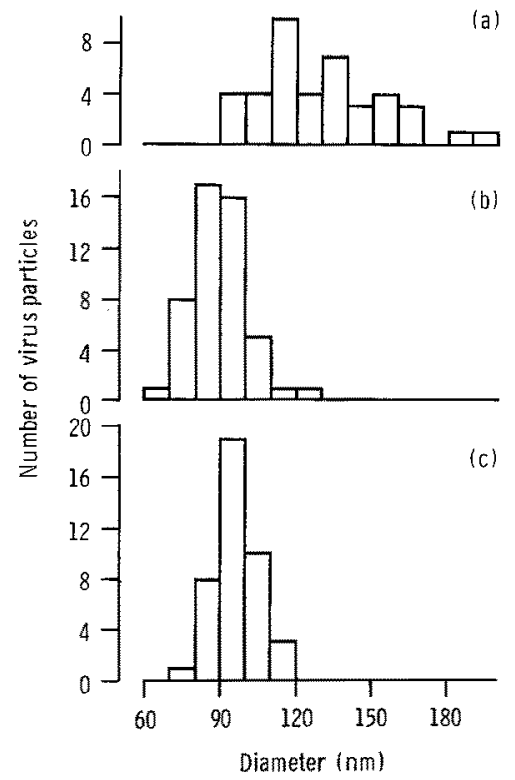

Fig. 2. Histograms of the envelope diameters of three coronaviruses determined using negative staining with 2 per cent potassium phosphotungstate, $\mathrm{pH}$ 6.5. a IBV Conn, $b \mathrm{HCV} 229 \mathrm{E}$ and $c \mathrm{MHV} 3$

Table 2. Lengths of the surface projections of three coronaviruses determined using different negative stains

\begin{tabular}{|c|c|c|c|c|c|c|c|c|}
\hline \multirow[b]{2}{*}{$\begin{array}{l}\text { Corona- } \\
\text { virus } \\
\text { species }\end{array}$} & \multicolumn{4}{|c|}{$\begin{array}{l}\text { Potassium phosphotungstate lengths } \\
\text { (nm) }\end{array}$} & \multicolumn{4}{|c|}{ Uranyl acetate lengths $(\mathrm{nm})^{\mathrm{b}}$} \\
\hline & $\begin{array}{l}\text { Number } \\
\text { of } \\
\text { obser- } \\
\text { vations }\end{array}$ & Mean & $\begin{array}{l}\text { Stand- } \\
\text { ard } \\
\text { error }\end{array}$ & Range & $\begin{array}{l}\text { Number } \\
\text { of } \\
\text { obser- } \\
\text { vations }\end{array}$ & Mean & $\begin{array}{l}\text { Stand- } \\
\text { ard. } \\
\text { error }\end{array}$ & Range \\
\hline IBV Conn & 70 & 19.8 & 0.35 & $12.8-27.3$ & 64 & 14.1 & 0.24 & $9.7-19.1$ \\
\hline $\mathrm{HCV} 229 \mathrm{E}$ & 89 & 20.3 & 0.19 & $15.6-23.8$ & 88 & 10.9 & 0.29 & $7.2-19.5$ \\
\hline MHV 3 & 104 & 19.7 & 0.15 & $16.6-23.4$ & 53 & 18.5 & 0.30 & $13.3-23.4$ \\
\hline
\end{tabular}

a Negative staining with 2 per cent potassium phosphotungstate, $\mathrm{pH}$ 6.5

- Negative staining with 0.5 per cent uranyl acetate, $\mathrm{pH} 4.4$

In spite of this difference in shape, the values of length shown in Table 2 were not found to be significantly different from each other when KPT staining was used. However, with UA staining, the three types were highly significantly different from each other $(\mathrm{p}<0.001)$, and all three were considerably shortened compared with their KPT values ( $\mathrm{p}<0.001$ in each case). 
Figures $3 \mathrm{a}$ and $\mathrm{b}$ show histograms of the lengths of the projections of IBV Conn and HCV $229 \mathrm{E}$ respectively, determined from KPT stained preparations. It is of interest to note that the lengths of the projections of IBV Conn show a much greater spread in values than $\mathrm{HCV} 229 \mathrm{E}$, but this difference in spread is not sufficient to invalidate the analysis of variance. The spread of lengths of projections of IBV Conn in UA stained preparations was similar to that obtained using KPT but HCV $229 \mathrm{E}$ and MHV 3 had a wider spread with UA than with KPT (not shown). In one preparation of $\mathrm{HCV} 229 \mathrm{E}$, projections were observed that were not consistent with the above description. A small percentage of particles in this preparation had projections that were thinner than the 'tear-drop' morphology, being 17 to $24 \mathrm{~nm}$ long and 3.9 to $5.6 \mathrm{~nm}$ wide. Projections of this type were not seen in preparations of IBV Conn.

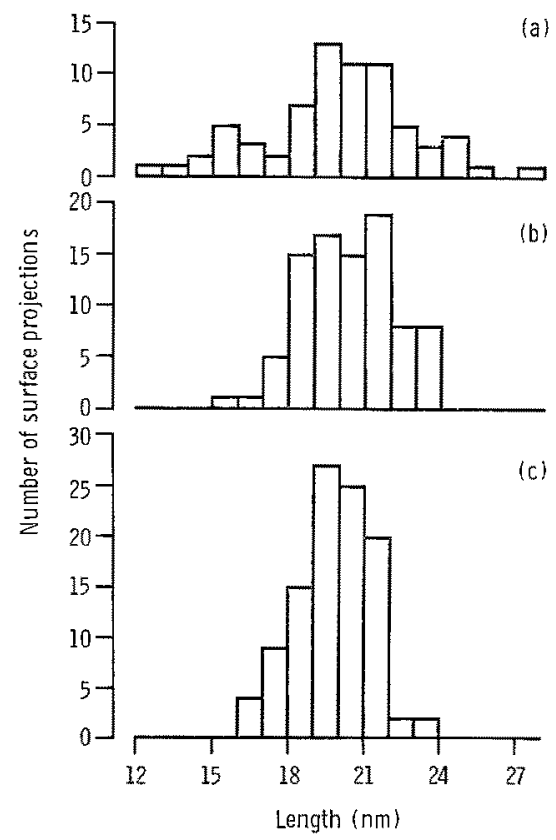

Fig. 3. Histograms of the lengths of the surface projections of three coronaviruses determined using negative staining with 2 per cent potassium phosphotungstate, $\mathrm{pH} 6.5$. $a$ IBV Conn, $b$ HCV $229 \mathrm{E}$ and $c$ MHV 3

Figure $3 \mathrm{c}$ shows a histogram of the spread of values using KPT for the length of MHV 3 surface projections. The spread was similar to that determined from UA treated preparations (not shown) and to KPT treated HCV $229 \mathrm{E}$ preparations (Fig. $3 \mathrm{~b}$ ). In three preparations of MHV 3, negatively stained with KPT a small percentage of the surface projections did not have the 'cone-shaped' morphology. These were bulbous in shape, 7.5 to $14 \mathrm{~nm}$ long and 6 to $11 \mathrm{~nm}$ wide.

Table 3 shows the widths of the surface projections. Here the main difference lies in the MHV 3 values being smaller than the others, while the IBV Conn values were a little greater than the HCV $229 \mathrm{E}$ values, and for each virus species the values using UA were rather greater than those using $\operatorname{KPT}(\mathrm{p}<0.001$ in every case). 
Table 3. Widths of the surface projections of three coronaviruses determined using different negative stains

\begin{tabular}{|c|c|c|c|c|c|c|c|c|}
\hline \multirow[b]{2}{*}{$\begin{array}{l}\text { Corona- } \\
\text { virus } \\
\text { species }\end{array}$} & \multicolumn{4}{|c|}{$\begin{array}{l}\text { Potassium phosphotangstate widths } \\
\qquad(\mathrm{nm})^{\mathrm{a}}\end{array}$} & \multicolumn{4}{|c|}{ Uranyl acetate widths $(\mathrm{nm})^{\mathrm{b}}$} \\
\hline & $\begin{array}{l}\text { Number } \\
\text { of } \\
\text { obser- } \\
\text { vations }\end{array}$ & Mean & $\begin{array}{l}\text { Stand- } \\
\text { ard } \\
\text { orror }\end{array}$ & Range & $\begin{array}{l}\text { Number } \\
\text { of } \\
\text { obser- } \\
\text { vations }\end{array}$ & Mean & $\begin{array}{l}\text { Stand- } \\
\text { ard } \\
\text { error }\end{array}$ & Range \\
\hline IBV Conn & 75 & 9.6 & 0.18 & $6.2-13.0$ & 63 & 10.5 & 0.16 & $7.4-13.0$ \\
\hline $\mathrm{HCV} 229 \mathrm{E}$ & 90 & 8.7 & 0.09 & $5.8-10.5$ & 66 & 9.8 & 0.17 & $7.7-13.0$ \\
\hline MHV 3 & 91 & 5.1 & 0.07 & $3.1-7.0$ & 53 & 5.5 & 0.16 & $2.7-8.2$ \\
\hline
\end{tabular}

a Negative staining with 2 per cent potassium phosphotungstate, pH 6.5

b Negative staining with 0.5 per cent uranyl acetate, $\mathrm{pH} 4.4$

\section{Effect of Purification on Virus Morphology}

Virus particles were also examined from partially purified samples in order to see if our purification procedure had had any effect on the virus morphology. Unfortunately, too few particles were present in crude clarified preparations to enable an accurate study to be made of them. However, pelleted virus preparations, before sucrose density gradient centrifugation, had sufficient virus particles present for analysis, although many of them were at least partially obscured by cell debris in MHV 3 preparations. Essentially no difference was observed in the morphology of the three coronavirus species between partially purified pelleted and purified virus particles, suggesting that our purification procedure has little effect on virus morphology.

\section{Diseussion}

The sizes of coronaviruses reported in the literature (15) vary widely, but it has not been clear how much of the variation was due to different methods of preparation, purification and negative staining, and whether different coronavirus species really do vary in size. Our results show that IBV Conn particles are much larger than those of $\mathrm{HCV} 229 \mathrm{E}$ and $\mathrm{MHV} 3$, and these may reflect significant molecular differences in their structures. In this respect it is interesting to note that the polypeptide compositions of IBV particles $(11,14)$ show significant differences from the polypeptide compositions of $\mathrm{HCV}(5,6,9)$ and $\mathrm{MHV}(9,19,20)$, although the RNA genomes of $\operatorname{IBV}(8,12,17)$ and $\operatorname{HCV}(13,21)$ show close similarities.

Most reports on coronavirus morphology, summarised by MoINTosh (15), have suggested that coronavirus particles have only one type of surface projection, the typical bulbous or 'tear-drop' shaped projection. However, a few reports $(1,3,4,16)$ have indicated the existence of another type of surface projection that is rod-shaped and sometimes has a spherical dilation or T-shaped structure at the distal end. Apparently, $\operatorname{IBV}(2,3,4)$ and haemagglutinating encephalomyelitis virus (16) particles can have different types of surface projections, whilst other coronavirus species have one or other type of surface projection. The bulbous HCV 229E and 'cone-shaped' MHV3 surface projections do not seem to consist of fundamentally different polypeptides as they are composed of glycopolypeptides

3 Areh. Virol. 59/1-2 
of similar size (MACNAUGHToN, unpublished results). However, the surface projections of IBV Conn are morphologically unlike those of MHV 3 and only superficially similar to those of $\mathrm{HCV} 229 \mathrm{E}$, and the IBV glycopolypeptides (14) are distinctly different from those of the other two viruses.

It is difficult to understand why the morphology of the surface projections is different. The differences cannot be attributed to staining procedures as identical methods were used for all three coronaviruses. The widely spaced typical bulbous coronavirus projections of $\mathrm{IBV}$ Conn and $\mathrm{HCV} 229 \mathrm{E}$ may reflect aggregations of the thinner, cone-shaped, MHV3-like projections which are more closely packed. This would explain how we have occasionally observed surface projections of different morphology in HCV $229 \mathrm{E}$ and MHV 3 preparations. Similarly, it would clarify previous reports that have shown certain coronavirus preparations to contain atypical surface projections. However, the different surface projections may be made up of similar glycopolypeptides that are arranged slightly differently, producing a different morphology, but exhibiting similar biological functions. It has been shown that staining virus particles with UA can vary the morphology of the projections of all three coronavirus species and the envelope diameters of HCV 229E and MHV 3. However, the action of UA as a negative stain is not understood. One suggestion is that UA is acidic and its reaction with polypeptides may depend on their isoelectric points (7).

It is important to determine how great is the morphological variation exhibited by coronavirus species and to establish whether such differences can be related to their biochemical structures. In this way it should be possible to establish whether such variations are significant and whether the coronavirus group should be subdivided.

\section{Acknowledgments}

We wish to thank Miss M. H. Madge for preparation of the viruses and Dr. R. R. Dourmashkin, Dr. M. V. Nermut, Dr. S. Patterson and Dr. D. A. J. Tyrrell for their advice and Dr. I. D. Hill for help with the statistics.

\section{References}

1. Caul, E. O., Egglestone, S. I.: Further studies on human enteric coronaviruses. Arch. Virol. 54, 107-117 (1977).

2. Coulins, M. S., Almxander, D. J., Harkness, J. W.: Heterogeneity of infeetions bronchitis virus grown in eggs. Arch. Virol. 50, 55-72 (1976).

3. EstorA, S., W ECKström, P.: Electron microscopy of infectious bronchitis virus. Ann. Med. exp. Biol. Fenn. 45, 30-31 (1967).

4. Harkness, J. W., Bracewell, C. D.: Morphological variation among avian infectious bronchitis virus strains. Res. vet. Sei. 16, 128-131 (1974).

5. Hierholzer, J. C.: Purification and biophysical properties of human coronavirus 229 E. Virology 75, 155-165 (1976).

6. Hierholzer, J. C., Patmer, E. L., Whirthield, S. G., Kaye, H. S., Dowdte, W. R.: Protein composition of coronavirus OC 43. Virology 48, 516-527 (1972).

7. Johansen, B. V., HoGLUNd, S.: Report on a symposium on contrast problems in transmission electron microscopy. Ultramicroscopy 1, 83-87 (1975).

8. Lomniczi, B., Kennedy, I.: Genome of infectious bronchitis virus. J. Virol. 24, $99-107(1977)$.

9. Macnadghton, M. R.: A comparison of the polypeptides of human and mouse coronaviruses. Submitted for publication. 
10. Madnaugiton, M. R., Davies, H. A., Nermut, M. V.: Ribonucleoprotein-like structures from coronavirus particles. J. gen. Virol. 39, 545-549 (1978).

11. Macnaughton, M. R., Madge, M. H.: The polypeptide composition of avian infectious bronchitis virus particles. Arch. Virol. 55, 47-54 (1977).

12. Macnaughton, M. R., Madge, M. H.: The characterisation of the virion RNA of avian infectious bronchitis virus. FEBS Letts. 77, 311-313 (1977).

13. Madnaughton, M. R., Madge, M. H.: The genome of human coronavirus strain 229 E. J. gen. Virol. 39, 497-504 (1978).

14. Macnaughton, M. R., Madge, M. H., Davies, H. A., Dourmashikin, R. R.: Polypeptides of the surface projections and the ribonucleoprotein of avian infectious bronchitis virus. J. Virol. 24, 821-825 (1977).

15. Mclstosh, K.: Coronaviruses: A comparative review. Curr. Top. Microbiol. Immunol. 63, 85-129(1974).

16. Pocock, D. H. : Effect of sulphydryl reagents on the biological activities, polypeptide composition and morphology of haemagglutinating encephalomyelitis virus. J. gen. Virol. 40, 93-101 (1978).

17. Sohochetman, G., Stevens, R. H., Stmpson, R. W.: Presence of infectious polyadenylated RNA in the coronavirus avian bronchitis virus. Virology 77, $772-782(1977)$.

18. Soxa, S. K., Shimada, N., ANDerson, P. J.: Orthoganol diameters in the analysis of muscle fibre size and form. Nature 200, $1220-1221$ (1963).

19. Sturmar, L. S.: Characterization of a coronavirus. I. Structural proteins: effects of preparative conditions on the migration of protein in polyacrylamide gels. Virology 77, 637-649 (1977).

20. Sturman, L. S., Holmes, K. V.: Characterization of a coronavirus. II. Glycoproteins of the viral envelope: tryptic peptide analysis. Virology 77, 650-660 (1977).

21. TANNock, G. A., Hierholzer, J. C.: The RNA of human coronavirus OC-43. Virology 78, 500-510 (1977).

22. Tyrreli, D. A. J., Almeida, J. D., Berry, D. M., Cunnmeham, C. H., Hamre, D., Hofstad, M. S., MallucoI, L., Molntosh, K. Coronaviruses. Nature 220, 650 (1968).

Authors' address: Dr. M. R. Macnaughton, Division of Communicable Diseases, Clinical Research Centre, Watford Road, Harrow, Middlesex HA 13 UJ, England.

Received June 30, 1978 